\title{
Stress responses of Synechocystis sp. strain PCC 6803 mutants impaired in genes encoding putative alternative sigma factors
}

\author{
Jana Huckauf, ${ }^{1}$ Chris Nomura, ${ }^{2}$ Karl Forchhammer ${ }^{3}$ \\ and Martin Hagemann ${ }^{1}$
}

1 Universität Rostock, FB Biologie, Institut für Molekulare Physiologie und Biotechnologie, Doberaner Str. 143, D-18051 Rostock, Germany

2 Department of Biochemistry and Molecular Biology, The Pennsylvania State University, University Park, PA 16802, USA

3 Justus-Liebig-Universität Giessen, Institut für Mikrobiologie und Molekularbiologie, Frankfurter Str. 107, D-35392 Giessen, Germany

\author{
Author for correspondence: Martin Hagemann. Tel: +49 381 4942076. Fax: +49 3814942079 \\ e-mail:mh@bio4.uni-rostock.de
}

In the complete genome sequence of the cyanobacterium Synechocystis sp. strain PCC 6803 [Kaneko et al. (1996). DNA Res 3, 109-136] genes were identified encoding putative group $3 \sigma$-factors SigH (SII-0856), SigG (SIr-1545) and SigF (SIr-1564) and the regulatory protein RsbU (SIr-2031). Mutations in these genes were generated by interposon mutagenesis to study their importance in stress acclimation. For the genes sigH, sigF and $r s b U$, the loci segregated completely. However, attempts to mutagenize the sigG locus resulted in merodiploids. Under standard growth conditions only minor differences were detected between the mutants and wild-type. However, cells of the RsbU mutant showed a clear defect in regenerating growth after a nitrogen- and sulphur-starvation-induced stationary phase. After applying salt, heat and high-light shocks, stress protein synthesis was analysed by means of one- and two-dimensional electrophoresis. Cells of the SigF mutant showed a severe defect in the induction of salt stress proteins. Although the acclimation to moderate salt stress up to $684 \mathrm{mM} \mathrm{NaCl}$ was not significantly changed in this mutant, its ability to acclimate to higher concentrations of $\mathrm{NaCl}$ was reduced. Northern blot experiments showed a constitutive expression of the rsbU and sigF genes. The expression of the sigH gene was found to be stressstimulated, particularly in heat-shocked cells, whilst that of sigG was transiently decreased under stress conditions. Possible functions of these regulatory proteins in stress acclimation of Synechocystis cells are discussed.

Keywords: cyanobacteria, environmental stress, sigma factors, stationary phase, stress proteins

\section{INTRODUCTION}

Processes of acclimation to environmental stresses in micro-organisms are mainly regulated at the level of transcriptional activation or repression. These alterations have been investigated by comparing the protein synthesis patterns of control and stressed cells. Differences between these patterns reflect changes in the actual gene expression programme (Hecker et al., 1996). Besides mechanisms that act on single genes, groups of genes are regulated in stressed cells via the activity of alternative sigma factors, which replace the primary sigma factor under unfavourable growth conditions.

Abbreviations: 1D, one-dimensional; 2D, two-dimensional; Km, kanamycin; PSII, photosystem II; WT, wild-type.
The eubacterial $\sigma$-factors can be principally divided into two evolutionarily distinct families, the $\sigma^{70}$ - and $\sigma^{54}$ related factors. The $\sigma^{70}$ family has been divided into several groups based upon the structural and functional properties of its members (Wösten, 1998). Group 1 comprises only the primary $\sigma$-factor, which is responsible for the transcription of most genes during exponential-growth phase and is essential for cell viability. Group 2 includes all nonessential primary-like $\sigma$-factors, which are structurally very close to the principal $\sigma$-factor. Group 3 contains alternative $\sigma$ factors, which are structurally different from proteins of group 1 and 2 and are involved in the transcription of special regulons necessary for flagella synthesis, heat shock response, sporulation or response to extracytoplasmic signals, etc. 
The cyanobacterial $\sigma^{70}$-like group 1 and the group 2 factors form evolutionarily distinct groups as deduced by comparing their sequences to homologous proteins from other eubacteria (Gruber \& Bryant, 1997). In the strains Synechocystis sp. PCC 6803 (Kaneko et al., 1996) and Synechococcus sp. PCC 7002 (Gruber \& Bryant, 1997), four group $2 \sigma$-factors have been identified in addition to the principal $\sigma$-factor. Additional group $2 \sigma$ factors were also found in the strains Anabaena sp. PCC 7120 (Brahamsha \& Haselkorn, 1992), Microcystis aeruginosa K-81 (Asayama et al., 1997), Synechococcus sp. PCC 7942 (Goto-Seki et al., 1999; Tsinomeras et al., 1996) and Nostoc punctiforme (Cambell et al., 1998). In vitro analysis has shown that the group 1 and some group $2 \sigma$-factors of Synechococcus sp. strain PCC 7942 exhibited the same promoter specificity (Goto-Seki et al., 1999). Several $\sigma$-factor-encoding genes were mutated to study their function in the cyanobacterial cell. One group $2 \sigma$-factor of Synechococcus sp. strain PCC 7002, called SigE, was found to be involved in the transcription of genes specifically expressed in post-exponential phase (Gruber \& Bryant, 1998), whilst the SigB and SigC proteins seem to be involved in responses to changes in carbon and nitrogen supply (Caslake et al., 1997). Cyanobacterial group $2 \sigma$-factors also play a role in the establishment of symbioses with plants and in circadianregulated gene expression (Cambell et al., 1998; Tsinomeras et al., 1996). According to extensive sequence comparisons, three genes of the complete genome sequence of Synechocystis sp. strain PCC 6803 putatively encode alternative $\sigma$-factors of group 3 (Table 1). They were initially named rpoE (sll-0856 and slr-1545) and rpoF (slr-1564) according to the closest eubacterial homologues (Kaneko et al., 1996). In most of the recent studies on cyanobacterial $\sigma$-factors, instead of $r p o$ these genes have been named using the sig nomenclature (Caslake et al., 1997; Gruber \& Bryant, 1997, 1998). To facilitate comparison with these studies on the strain Synechococcus sp. PCC 7002, the genes for putative group $3 \sigma$-factors of Synechocystis sp. strain PCC 6803 were in this study designated according to their closest homologues in Synechococcus sp. strain PCC 7002: sigF (rpoF, slr-1564), sigG (rpoE, slr-1545) and sigH (rpoE, sll-0856). Recently, a SigF mutant of Synechocystis sp. strain PCC 6803 was constructed and it was found that this mutant has a defect in phototactic movement (Bhaya et al., 1999).

Cyanobacterial acclimation to extreme environmental conditions such as high temperatures, changing salinities, high light intensities, etc., is accompanied by the expression of a special set of stress proteins (e.g. Fulda et al., 1999; Hagemann et al., 1991; Webb \& Sherman, 1994). These stress proteins can be divided into two groups, special stress proteins, which are only induced by a defined stress, and general stress proteins, which are induced by several stresses (Hagemann et al., 1991). In cyanobacteria, the molecular mechanisms involved in the activation of gene expression during acclimation processes are mostly unknown. As in other bacteria, cyanobacteria may use alternative $\sigma$-factors to regulate the expression of stress proteins. Group $3 \sigma$-factors, which include the extracytoplasmic-function-(ECF)$\sigma$-factors, are also often involved in environmental acclimation processes of Gram-negative bacteria (Missiakas \& Raina, 1998). The induction of general stress proteins, such as osmotically and stationaryphase-regulated proteins, in Escherichia coli and other Gram-negative bacteria is driven by RpoS (HenggeAronis, 1996). RpoS homologues form a distinct group among $\sigma^{70}$-like-factors, to which none of the cyanobacterial group 2 factors bear homology (Gruber \& Bryant, 1997). In Gram-positive bacteria such as Bacillus subtilis, general stress proteins form the SigB-dependent operon (Hecker et al., 1996). This group $3 \sigma$-factor is activated by internal and external stimuli. These signals are transmitted via several proteins of the $r s b$ operon, which act as anti- $\sigma$-factors, protein kinases or phosphatases. In particular, the protein phosphatase RsbU plays a central role in SigB activation under environmental stress (Hecker et al., 1996). A close homologue to RsbU has been identified in the genome of Synechocystis sp. strain PCC 6803 (Table 1), which is encoded by the ORF slr-2031 (Kaneko et al., 1996).

To define the role of alternative sigma factors in cyanobacterial acclimation to environmental stresses, genes encoding putative group $3 \sigma$-factors $(\mathrm{SigF}$, SigG and $\mathrm{SigH}$ homologues) and the RsbU homologue (Kaneko et al., 1996) in the strain Synechocystis sp. PCC 6803 were selected to generate mutants defective in these genes. The acclimation of these mutants to environmental stresses was analysed. Stress protein synthesis and expression of the sig and rsbU genes were characterized. Furthermore, the survival time under lethal stress treatments was compared.

\section{METHODS}

Strains and culture conditions. A derivative of the Synechocystis sp. strain PCC 6803 (henceforth referred to as Synechocystis) with enhanced transforming capacity was used in all experiments and was obtained from S. Shestakov (Moscow State University, Russia). Synechocystis belongs to the group of moderately halotolerant cyanobacteria resisting up to $1 \cdot 2 \mathrm{M} \mathrm{NaCl}$ by accumulating the compatible solute glucosylglycerol (Reed \& Stewart, 1985). Axenic cells were cultivated in batch cultures at $30{ }^{\circ} \mathrm{C}$ with $\mathrm{CO}_{2}$-enriched air $(5 \%, \mathrm{v} / \mathrm{v})$ and constant illumination $\left(170 \mu \mathrm{mol} \mathrm{m} \mathrm{m}^{-2} \mathrm{~s}^{-1}\right)$ using a potassium-nitrate-containing standard medium with $2 \mathrm{mM}$ $\mathrm{NaCl}$ (Allen \& Arnon, 1955). Salt treatment experiments were performed in batch cultures of mutant and wild-type (WT) cells after addition of $\mathrm{NaCl}$ (usually up to $684 \mathrm{mM}$ ) to the standard medium. For heat and high-light shock experiments, cultures were transferred to $43^{\circ} \mathrm{C}$ and to $2000 \mu \mathrm{mol} \mathrm{m}{ }^{-2} \mathrm{~s}^{-1}$, respectively, for the times indicated in the figures and tables. To test recovery from the stationary phase, mutant and WT cells were pre-cultured in BG11 medium (Rippka et al., 1979) in shaking Erlenmeyer flasks at $30{ }^{\circ} \mathrm{C}$ and $65 \mu \mathrm{mol} \mathrm{m}{ }^{-2} \mathrm{~s}^{-1}$ white light. To induce stationary phase, cells were harvested by centrifugation $(10 \mathrm{~min}, 5000 \mathrm{~g}$ ), washed twice with $\mathrm{N}$-free BG11 and cultured in N-free BG11 medium for two weeks. Thereafter, cells were harvested by centrifugation and transferred into N-containing BG11 medium to observe recovery 
Table 1. Sequence comparisons of the Synechocystis proteins (Kaneko et al., 1996) that were analysed in this study, indicating that they are putative group $3 \sigma$-factors and a regulatory protein

Only those similar proteins which have been functionally characterized are shown.

\begin{tabular}{|c|c|c|c|c|}
\hline $\begin{array}{l}\text { Synechocystis } \\
\text { protein }\end{array}$ & $\begin{array}{l}\text { Identity/ } \\
\text { similarity } \\
\quad(\%)\end{array}$ & $\begin{array}{l}\text { Bacterial homologue } \\
\text { (protein, organism) }\end{array}$ & $\begin{array}{l}\text { Regulatory functions of } \\
\text { homologue }\end{array}$ & Reference \\
\hline Slr-1564/SigF & $\begin{array}{l}31 / 53 \\
31 / 49\end{array}$ & $\begin{array}{l}\text { SigB, Bacillus subtilis* } \\
\text { SigF, Streptomyces setonii }\end{array}$ & $\begin{array}{l}\text { General stress response } \\
\text { Carotenoid biosynthesis } \\
\text { Morphological differentiation }\end{array}$ & $\begin{array}{l}\text { Hecker et al. (1996) } \\
\text { Kato et al. (1995) } \\
\text { Potuckova et al. (1995) }\end{array}$ \\
\hline Slr-1545/SigG & $\begin{array}{l}32 / 48 \\
33 / 48 \\
28 / 45\end{array}$ & $\begin{array}{l}\text { AlgU, Pseudomonas aeruginosa } \\
\text { RpoE, Escherichia coli* } \\
\text { FecI, Escherichia coli }\end{array}$ & $\begin{array}{l}\text { Alginate biosynthesis and stress } \\
\text { tolerance } \\
\text { Response to strong heat shocks } \\
\text { Iron transport and acquisition }\end{array}$ & $\begin{array}{l}\text { Martin et al. (1993) } \\
\text { Gross (1996) } \\
\text { Van Hove et al. (1990) }\end{array}$ \\
\hline Sll-0856/SigH & $\begin{array}{l}32 / 50 \\
32 / 52\end{array}$ & $\begin{array}{l}\text { AlgU, Pseudomonas aeruginosa } \\
\text { RpoE, Escherichia coli* }\end{array}$ & $\begin{array}{l}\text { Alginate biosynthesis and stress } \\
\text { tolerance } \\
\text { Response to strong heat shocks }\end{array}$ & $\begin{array}{l}\text { Martin et al. (1993) } \\
\text { Gross (1996) }\end{array}$ \\
\hline Slr-2031/RsbU & $27 / 46$ & RsbU, Bacillus subtilis* & $\begin{array}{l}\text { Protein phosphatase activating } \\
\text { SigB }\end{array}$ & Völker et al. (1995) \\
\hline
\end{tabular}

* Comparable similarities were found to many functionally related proteins from other Gram-positive and Gram-negative bacteria.

Table 2. Primers used to amplify DNA fragments containing genes of Synechocystis sp. strain PCC 6803 (Kaneko et al., 1996)

Restriction sites are shown in bold letters.

\begin{tabular}{|c|c|c|}
\hline Designation & Primer & Enzyme \\
\hline SIGF $5 *$ & 5'-CTTTAGTCCATGGGGATCTG-3' & NcoI \\
\hline SIGF 3* & 5'-GCGATCGCCATGGCCTAGAC-3' & NcoI \\
\hline SIGH $5 *$ & 5'-GACTGAGTTTAAACGGGTTC-3' & DraI \\
\hline SIGH $3 *$ & 5'-ACGGGAATTTAAACGGCGTT-3' & DraI \\
\hline SIGG 5* & 5'-ATTACTGGCCACGGCATTGT-3' & BalI \\
\hline SIGG $3 *$ & 5'-TCTTCATCCATGGCTACGAT-3' & NcoI \\
\hline RSBU 5* & 5'-CAGGTTCAAGCTTTGCAAAA-3' & HindIII \\
\hline RSBU 3* & 5'-AGCGAGGATATCAATGGAT-3' & EcoRV \\
\hline SIGFP $5 \dagger$ & 5'-ATGACCAATGCCACCAGCGA-3' & - \\
\hline SIGFP $3 \dagger$ & 5'-TCCGTATTTAAGGCTTTTTT-3' & - \\
\hline SIGHP $5 \dagger$ & 5'- GAGGCCTTTCGTCAACTTTA -3' & - \\
\hline SIGHP $3 \dagger$ & 5'- TTAAAAGACATCTTGAACTC -3' & - \\
\hline SIGGP $5+$ & 5'-GTGTTGGGTAAATCCATCAA-3' & - \\
\hline SIGGP $3 \dagger$ & 5'-CCAAATAGGGCTGTAAAAAA-3' & - \\
\hline RSBUP5† & 5'-TCAAGGAGTTGGTGGCTAAG-3' & - \\
\hline RSBUP3† & 5'-TCACTCCGTCGATTTTACCC-3' & - \\
\hline groEL-fw† & 5'-CATGGACATTCTGGCGGAAG-3' & - \\
\hline groEL-rev† & 5'-GGTCAATACCATGCCAGCGA-3' & - \\
\hline 16SrDNA27f $†$ & 5'-AGAGTTTGATCMTGGCTCAG-3'ł & - \\
\hline 16SrDNA1525† & 5'-AAGGAGGTGWTCCARCC-3’ł & - \\
\hline
\end{tabular}

*Primers used to construct mutants (see Fig. 1).

† Primers used to generate gene-specific probes for Northern blot experiments.

$\ddagger$ Primer sequences according to Lane (1991). 

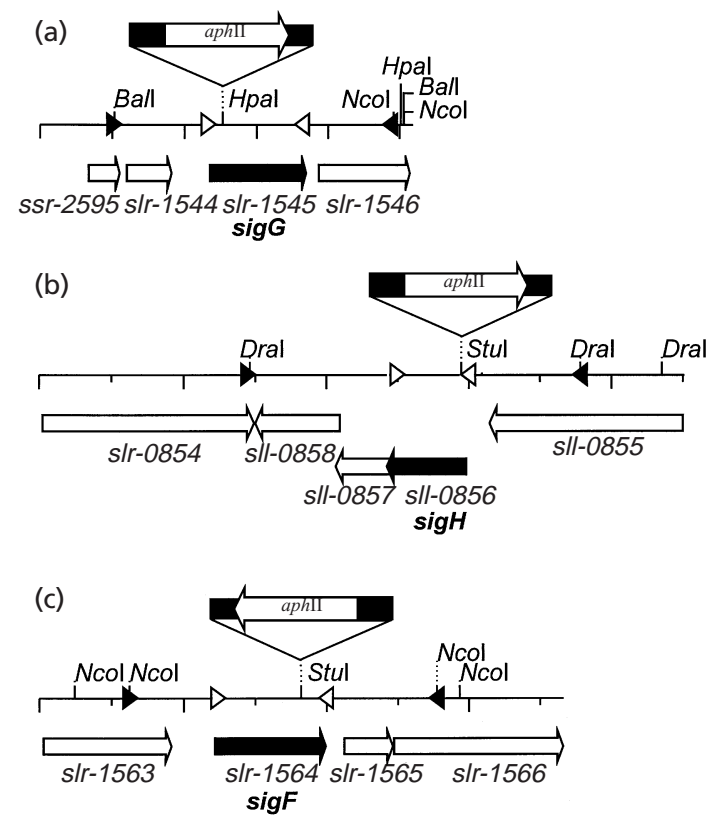

(d)

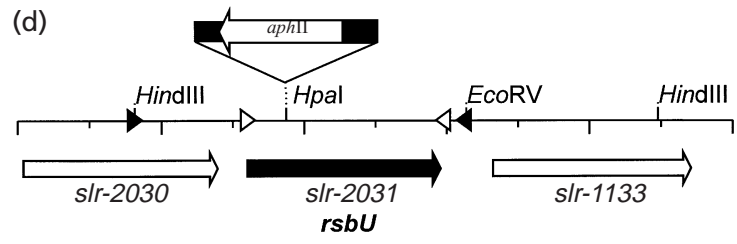

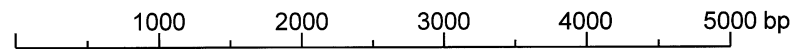

Fig. 1. Schematic drawing showing the genetic organization, restriction map and protein-encoding region of the chromosomal sites affected in the Synechocystis sp. strain PCC 6803 mutants SigG (a), SigH (b), SigF (c) and RsbU (d). The sequences of the protein-encoding regions were taken from the complete genome sequence of this strain (Kaneko et al., 1996). The sites of insertion of the aphll gene cartridges into the different genes so as to obtain directed mutants of different ORFs are shown above each region. Black triangles, primer binding sites used to generate mutants; open triangles, primer-binding sites used to generate gene-specific probes; black arrows, affected genes; open arrows, genes neighbouring affected genes.

from the starvation-induced stationary phase. The survival of lethal stresses was tested by incubation of cyanobacterial cells in test tubes under stress conditions close to the maximal resistance levels $\left(45^{\circ} \mathrm{C}, 4{ }^{\circ} \mathrm{C}, 855 \mathrm{mM} \mathrm{NaCl}, 2000 \mu \mathrm{mol}\right.$ photons $\mathrm{m}^{-2} \mathrm{~s}^{-1}$, complete lack of single nutrients). After different incubation times (hours to weeks depending on the particular stress, see text), $1 \mathrm{ml}$ samples were taken from the test tubes. The cells were collected by centrifugation $(10 \mathrm{~min}$, $5000 \mathrm{~g}$ ) and resuspended in BG11 medium. Defined aliquots were dropped onto Petri dishes containing medium C (Kratz \& Myers, 1955) supplemented with $0 \cdot 8 \%$ agar. After incubation of the plates at $29^{\circ} \mathrm{C}$ and continuous light of $20 \mu \mathrm{mol} \mathrm{m} \mathrm{m}^{-2} \mathrm{~s}^{-1}$ for one week, surviving cells were evaluated and documented by photography. The E. coli strain TG1 (Sambrook et al., 1989) was used for routine DNA manipulations. E. coli was cultivated in Luria broth medium (Sambrook et al., 1989) at $37^{\circ} \mathrm{C}$.
DNA manipulations. Total DNA from Synechocystis was isolated according to Hagemann et al. (1996). Chromosomal DNA for PCR analyses was obtained after treatment of $200 \mu \mathrm{l}$ cyanobacterial solution with hot phenol and chloroform. All other techniques, such as plasmid isolation, transformation of E. coli, ligation and restriction analysis (restriction enzymes were obtained from New England Biolabs) were standard methods (Sambrook et al., 1989). DNA probes were labelled with digoxigenin for Southern hybridization using the PCR DIG Probe Synthesis kit (Boehringer Mannheim). DNA and protein sequences were analysed using DNASIS/PROSIS, CLUSTAL X and BLAST (Altschul et al., 1997) software packages. For the PCR reactions, PCR-supermix or Elongase (Life Technologies) and the following temperature cycle was applied $(\times 30): 15 \mathrm{~s}$ at $94^{\circ} \mathrm{C}, 30 \mathrm{~s}$ at $52^{\circ} \mathrm{C}, 2 \mathrm{~min}$ at $72{ }^{\circ} \mathrm{C}$.

Generation of insertion mutants. Mutants impaired in selected genes were generated by reverse genetics. The coding sequences and neighbouring sequences were amplified by PCR. The approximately $2 \mathrm{~kb}$ PCR products were cloned into pUCBM20/21 (Boehringer Mannheim). The primers for amplification were designed using the complete genome sequence of Synechocystis (Kaneko et al., 1996). Sequences were selected which contained appropriate restriction sites to improve cloning of the fragments (Table 2). The aphII gene [aminoglycoside phosphotransferase II conferring kanamycin $(\mathrm{Km})$ resistance] isolated from plasmid pUC4K (Pharmacia) was inserted into unique restriction sites of the encoding sequences. Transformation of Synechocystis has been described previously (Hagemann \& Zuther, 1992). Transformants were initially selected on medium C (Kratz \& Myers, 1955) containing $10 \mu \mathrm{g} \mathrm{Km} \mathrm{ml}{ }^{-1}$ (Sigma), whilst the segregation of clones was performed by restreaking of primary clones on plates supplemented with $50 \mu \mathrm{g} \mathrm{Km} \mathrm{ml}{ }^{-1}$ several times (at least three transfers). During cultivation of mutants, $50 \mu \mathrm{g} \mathrm{Km} \mathrm{ml}{ }^{-1}$ was added to the liquid media.

Protein labelling and electrophoretic separation. For labelling of proteins, $5 \mathrm{ml}$ cells was incubated with $2.8 \mathrm{MBq} \mathrm{L-}$ $\left.{ }^{35} \mathrm{~S}\right]$ methionine (specific activity $>29.6 \mathrm{TBq} \mathrm{mmol}^{-1}$; Amersham Buchler) for 30 min under the culture or shock conditions described above, but without bubbling with $\mathrm{CO}_{2}$ enriched air. Proteins were extracted in $10 \mathrm{mM} \mathrm{HEPES/}$ $\mathrm{NaOH}$ ( $\mathrm{pH} 7 \cdot 3$ ) containing $1 \mathrm{mM}$ PMSF by means of an icecooled cell mill (E. Buhler) with glass beads (diameter $0 \cdot 1-0 \cdot 2 \mathrm{~mm}$ ) twice for $1 \mathrm{~min}$. The homogenate was centrifuged $\left(48000 \mathrm{~g}, 4{ }^{\circ} \mathrm{C}\right.$; Sorvall) and the supernatant was stored at $-20{ }^{\circ} \mathrm{C}$. After estimation of $\left[{ }^{35} \mathrm{~S}\right]$ methionine incorporation, aliquots of the samples were concentrated by lyophilization. Equal amounts of radioactivity $\left(10^{5}\right.$ and $10^{6}$ c.p.m. for one- and two-dimensional separations, respectively) were applied to each lane or gel. One-dimensional (1D) SDS-PAGE was performed as described previously (Fulda et al., 1999). The molecular masses of protein bands were determined in comparison to labelled rainbow protein standards (Amersham Buchler) by videodensitometry with the Bioprofil 1D software (Vilbert Lourmat). For two-dimensional (2D) PAGE separations (SDS used in the second dimension), the 2D Investigator system (Millipore) was applied, following exactly the instructions of the manufacturer regarding the preparation and running of IEF and PAGE gels.

RNA isolation and Northern blot experiments. RNA was isolated from cells of $10 \mathrm{ml}$ culture, which were harvested by centrifugation $\left(4000 \mathrm{~g}, 10 \mathrm{~min}, 2^{\circ} \mathrm{C}\right)$, immediately frozen and stored at $-80^{\circ} \mathrm{C}$. RNA was extracted using the High Pure RNA Isolation kit (Boehringer Mannheim). Methods used for the separation of RNA, blotting and hybridization were 
Table 3. Plasmids and Synechocystis sp. strain PCC 6803 mutants used and constructed in this study (see also Fig. 1)

\begin{tabular}{|c|c|}
\hline Plasmid or mutant & Description \\
\hline \multicolumn{2}{|l|}{ Plasmids } \\
\hline $\mathrm{pNsigF}$ & $\begin{array}{l}\text { pUCBM } 20 \text { containing sigF (slr-1564) as a } 2 \cdot 1 \mathrm{~kb} \mathrm{NcoI} \mathrm{fragment} \mathrm{obtained} \\
\text { by PCR with SIGF } 5 \text { and SIGF } 3 \text { primers; final size, } 4.87 \mathrm{~kb}\end{array}$ \\
\hline pNFSK & $\begin{array}{l}\text { pNsigF containing an inactivated } \operatorname{sig} F \text { gene }(a p h I I \text { gene is inserted at the } \\
\text { unique } S t u \text { I site in opposite direction to } \operatorname{sig} F) \text {; final size, } 6.12 \mathrm{~kb}\end{array}$ \\
\hline pSNG & $\begin{array}{l}\text { pUCBM } 21 \text { containing } \operatorname{sig} G(s l r-1545) \text { as a } 1.9 \mathrm{~kb} \text { Ball } / \text { NcoI fragment } \\
\text { obtained by PCR with SIGG } 5 \text { and SIGG } 3 \text { primers; final size, } 4.58 \mathrm{~kb}\end{array}$ \\
\hline pSNGHK & $\begin{array}{l}\text { pSNG containing an inactivated } \operatorname{sig} G \text { gene }(a p h I I \text { gene is inserted at the } \\
\text { unique } H p a \mathrm{I} \text { site in the same direction as } \operatorname{sig} G) \text {; final size, } 5.83 \mathrm{~kb}\end{array}$ \\
\hline $\mathrm{pSsigH}$ & $\begin{array}{l}\text { pUCBM } 21 \text { containing sigH (sll-0856) as a } 2.3 \mathrm{~kb} \text { Dral fragment obtained } \\
\text { by PCR with SIGH } 5 \text { and SIGH } 3 \text { primers; final size, } 5.04 \mathrm{~kb}\end{array}$ \\
\hline pSsigHSK & $\begin{array}{l}\text { pSsigH containing an inactivated sigH gene }(a p h I I \text { gene is inserted at the } \\
\text { unique } S t u \text { I site in opposite direction to } \operatorname{sig} H) \text {; final size, } 6.29 \mathrm{~kb}\end{array}$ \\
\hline pHSU & $\begin{array}{l}\text { pUCBM } 20 \text { containing } r s b U(s l r-2031) \text { as a } 2.32 \mathrm{~kb} H \text { indIII/EcoRV } \\
\text { fragment obtained by PCR with RSBU } 5 \text { and RSBU } 3 \text { primers; final } \\
\text { size, } 4.96 \mathrm{~kb}\end{array}$ \\
\hline pHSUHK & $\begin{array}{l}\text { pHSU containing an inactivated } r s b U \text { gene }(a p h I I \text { gene is inserted at the } \\
\text { unique } H p a \mathrm{I} \text { site in opposite direction to } r s b U) \text {; final size, } 6.21 \mathrm{~kb}\end{array}$ \\
\hline \multicolumn{2}{|l|}{ Mutants } \\
\hline SigF mutant & $\begin{array}{l}\text { Synechocystis mutant impaired in sigF (slr-1564) obtained after } \\
\text { transformation of the WT with pNFSK }\end{array}$ \\
\hline SigH mutant & $\begin{array}{l}\text { Synechocystis mutant impaired in sigH (sll-0856) obtained after } \\
\text { transformation of the WT with pSsigHSK }\end{array}$ \\
\hline SigG mutant & $\begin{array}{l}\text { Synechocystis mutant impaired in sigG }(s l r-1545) \text { obtained after } \\
\text { transformation of the WT with pSNGHK }\end{array}$ \\
\hline RsbU mutant & $\begin{array}{l}\text { Synechocystis mutant impaired in } r s b U(s l r-2031) \text { obtained after } \\
\text { transformation of the WT with pHSUHK }\end{array}$ \\
\hline
\end{tabular}

described in detail previously (Hagemann et al., 1997). Genespecific DNA probes for the Northern blot experiments were obtained after PCR amplification of the coding sequences of the corresponding genes using primers (see Table 2) binding to their $5^{\prime}$ and $3^{\prime}$ ends. The DNA was labelled with $\left[\alpha^{-32} \mathrm{P}\right] \mathrm{dATP}$ (Amersham Buchler) using a random prime labelling kit (MBI Fermentas). Hybridization signals were recorded and quantified by means of a phosphorimager (BAS1000; Fuji). To quantify the data and correct errors in gel loading, all calculations were made on the basis of hybridization signals obtained after applying a radiolabelled $16 \mathrm{~S}$ rDNA probe (for primers see Table 2) to the same filters.

Physiological characterization. The content of low-molecularmass stress metabolites was analysed by HPLC (Hagemann et al., 1997). Photosynthetic oxygen evolution in the light and respiratory oxygen consumption in the dark were measured using a Clark-type electrode. Growth and cell density were monitored by reading the optical density of diluted cyanobacterial suspensions at $750 \mathrm{~nm}$ using a spectrophotometer (U2000; Hitachi). Pigment concentrations were estimated using in vivo absorption measurements (U2000; Hitachi) and the formulae for corrections of peak interferences (Sigalat \& de Kouchkovsky, 1975). Degradation of pigments in nitrogenstarved cells was followed by reading whole-cell absorbance spectra, which were corrected for cell scattering (Sauer et al., 1999). Photosystem II (PSII) fluorescence with and without $10 \mu \mathrm{M}$ 3-(3,4-dichlorophenyl)-1,1-dimethylurea (DCMU) was recorded using a microplate fluorimeter (Fluoroscan II;
Labsystems) after excitation at $570 \mathrm{~nm}$ and emission at $685 \mathrm{~nm}$.

All experiments were repeated at least three times using independent cultures. In the tables and figures, means and standard deviations are given or the results of one typical experiment are shown.

\section{RESULTS}

\section{Generation of mutants}

To study the importance of group $3 \sigma$-factors for stress acclimation of Synechocystis, mutants affected in three genes encoding these $\sigma$-factors and in the regulatory protein RsbU were generated by interposon mutagenesis. After PCR amplification and cloning of coding sequences together with flanking sequences, the aphII resistance gene cassette was introduced into unique restriction sites. The plasmid DNA of Km-resistant E. coli clones was analysed by PCR and restriction analyses. For further experiments, constructs in which the aphII gene was inserted in a transcription direction opposite to that of $\operatorname{sig} H, \operatorname{sig} F$ and $r s b U$ were selected, except for $\operatorname{sig} G$ for which plasmids were only obtained with the aphII gene integrated collinearly (Fig. 1, Table 3). Synechocystis WT cells were transformed with 


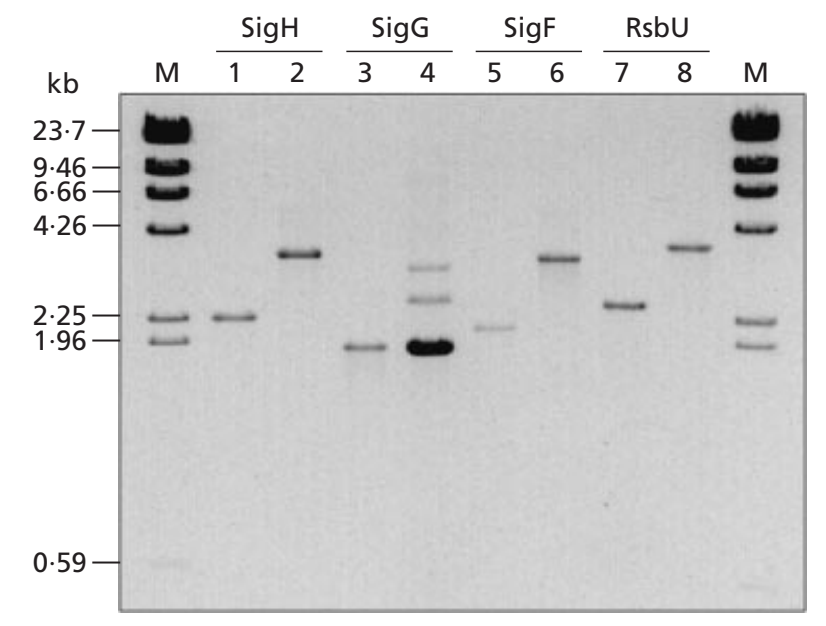

Fig. 2. $P C R$ analyses using chromosomal DNA of the WT (lanes 1, 3, 5 and 7) and of mutants (lane 2, SigH ; lane 4, SigG; lane 6, SigF; lane 8, RsbU; see Fig. 1, Table 3) of Synechocystis sp. strain PCC 6803 as a template and primers specific for selected genes (lanes 1 and 2, SIGH 5 and SIGH 3; lanes 3 and 4, SIGG 5 and SIGG 3; lanes 5 and 6, SIGF 5 and SIGF 3; lanes 7 and 8, RSBU 5 and RSBU 3; see Table 2) in order to verify the lesions in the chromosomal DNA of the mutants. Lane M, Hindlll-cut DNA used as fragment size marker.

plasmids harbouring inactivated genes putatively encoding $\sigma$-factors and RsbU- and Km-resistant clones were selected.

Segregation was performed by restreaking of primary colonies on plates supplemented with $50 \mu \mathrm{g} \mathrm{Km} \mathrm{ml}{ }^{-1}$ for at least three weeks. The DNA of mutant clones was analysed by PCR using the same primers that were used to amplify the DNA fragments from WT DNA. In all cases, using mutant DNA the PCR reactions produced enlarged fragments compared to the fragments obtained with WT DNA (Fig. 2). The size differences exactly corresponded to the increases expected following insertion of an aphII gene cassette $(1 \cdot 2 \mathrm{~kb})$. Furthermore, when DNA of the SigH, SigF and RsbU mutants was used, the WT fragments were completely absent (Fig. 2). Only in DNA of the SigG mutant did a dominant fragment corresponding to the size of the WT DNAfragment remain visible, indicating incomplete segregation of the genome of this mutant. Additionally, a fragment of intermediate size was generated, which probably resulted from an intramolecular template exchange by the elongase enzyme mix. All attempts to obtain a completely segregated SigG mutant or to minimize the proportion of the WT-size fragment using cultivation at enhanced $\mathrm{Km}$ concentrations or different salt and temperature conditions failed, indicating that this gene is essential for Synechocystis under all growth conditions tested in this study. The results of the PCR analyses were confirmed by Southern hybridization experiments (not shown).

\section{Physiological characterization}

Initially, growth and pigmentation of the mutants were compared to the WT under standard growth conditions (Table 4). Surprisingly, only the SigG mutant showed a decreased growth rate in spite of its incomplete segregation. No significant differences in pigment contents could be detected between the WT and sig mutants. However, cells of the RsbU mutant exhibited an increased pigmentation under our standard growth conditions. Photosynthetic and respiratory activities

Table 4. Comparison of physiological parameters of WT and mutant cells of Synechocystis sp. strain PCC 6803 after cultivation at a low salt concentration of $2 \mathrm{mM} \mathrm{NaCl}$

Values are means \pm SD.

\begin{tabular}{|c|c|c|c|c|c|}
\hline Parameter* & WT & SigH & SigG & SigF & RsbU \\
\hline Growth rate $\left(\mathrm{h}^{-1}\right)$ & $0.0399 \pm 0.0063$ & $0 \cdot 0367 \pm 0 \cdot 004$ & $0.0285 \pm 0 \cdot 0049$ & $0 \cdot 0400 \pm 0 \cdot 006$ & $0 \cdot 386 \pm 0 \cdot 0051$ \\
\hline $\begin{array}{l}\text { Photosynthetic oxygen evolution } \\
\left(\mathrm{mg} \mathrm{O}_{2}^{-1} \mathrm{~h}^{-1} \mu \mathrm{mol} \mathrm{Chl} a^{-1}\right)\end{array}$ & $2 \cdot 83 \pm 0 \cdot 83$ & $2 \cdot 84 \pm 0 \cdot 44$ & $3 \cdot 24 \pm 0 \cdot 87$ & $3 \cdot 05 \pm 1 \cdot 07$ & $2 \cdot 44 \pm 0.75$ \\
\hline PSII fluorescence ratio $\left(F_{\mathrm{v}} / F_{\max }\right)$ & $0 \cdot 401 \pm 0 \cdot 016$ & $0 \cdot 416 \pm 0 \cdot 012$ & $0 \cdot 389 \pm 0 \cdot 020$ & $0 \cdot 416 \pm 0 \cdot 014$ & $0 \cdot 446 \pm 0 \cdot 009$ \\
\hline $\begin{array}{l}\text { Respiratory oxygen consumption } \\
\left(\mathrm{mg} \mathrm{O}_{2}^{-1} \mathrm{~h}^{-1} \mu \mathrm{mol} \mathrm{Chl} a^{-1}\right)\end{array}$ & $0 \cdot 40 \pm 0 \cdot 13$ & $0 \cdot 37 \pm 0 \cdot 15$ & $0 \cdot 40 \pm 0 \cdot 15$ & $0 \cdot 43 \pm 0 \cdot 21$ & $0 \cdot 32 \pm 0 \cdot 27$ \\
\hline $\begin{array}{l}\text { Chl a content }\left(\mu \mathrm{mol} \mathrm{Chl} a \mathrm{l}^{-1}\right. \\
\left.\mathrm{OD}_{750} \mathrm{unit}^{-1}\right)\end{array}$ & $1 \cdot 736 \pm 0 \cdot 095$ & $1 \cdot 650 \pm 0 \cdot 096$ & $1 \cdot 441 \pm 0 \cdot 268$ & $1 \cdot 598 \pm 0.094$ & $2 \cdot 179 \pm 0 \cdot 176$ \\
\hline $\begin{array}{l}\text { Car content ( } \mu \mathrm{mol} \mathrm{Car}{ }^{-1} \mathrm{OD}_{750} \\
\left.\text { unit }^{-1}\right)\end{array}$ & $2 \cdot 458 \pm 0 \cdot 524$ & $2 \cdot 701 \pm 0 \cdot 752$ & $1.938 \pm 0.698$ & $2 \cdot 88 \pm 0 \cdot 504$ & $4 \cdot 727 \pm 0 \cdot 829$ \\
\hline $\begin{array}{l}\text { PC content }\left(\mu \mathrm{mol} \mathrm{PC} l^{-1} \mathrm{OD}_{750}\right. \\
\left.\text { unit }^{-1}\right)\end{array}$ & $0 \cdot 508 \pm 0 \cdot 086$ & $0 \cdot 525 \pm 0 \cdot 125$ & $0 \cdot 391 \pm 0 \cdot 116$ & $0 \cdot 551 \pm 0 \cdot 075$ & $0 \cdot 834 \pm 0 \cdot 114$ \\
\hline $\begin{array}{l}\text { GG content ( } \mu \mathrm{g} \mathrm{GG} \mathrm{ml}^{-1} \mathrm{OD}_{750} \\
\left.\text { unit }^{-1}\right) \dagger\end{array}$ & $36 \cdot 87 \pm 0.55$ & $41 \cdot 38 \pm 0.51$ & $43 \cdot 10 \pm 1 \cdot 15$ & $40 \cdot 15 \pm 0 \cdot 99$ & $38 \cdot 04 \pm 1 \cdot 00$ \\
\hline
\end{tabular}

* Car, carotenoid; Chl a, chlorophyll $a$; GG, glucosylglycerol; PC, phycocyanin.

† After acclimation to a high salt concentration of $684 \mathrm{mM} \mathrm{NaCl}$. 

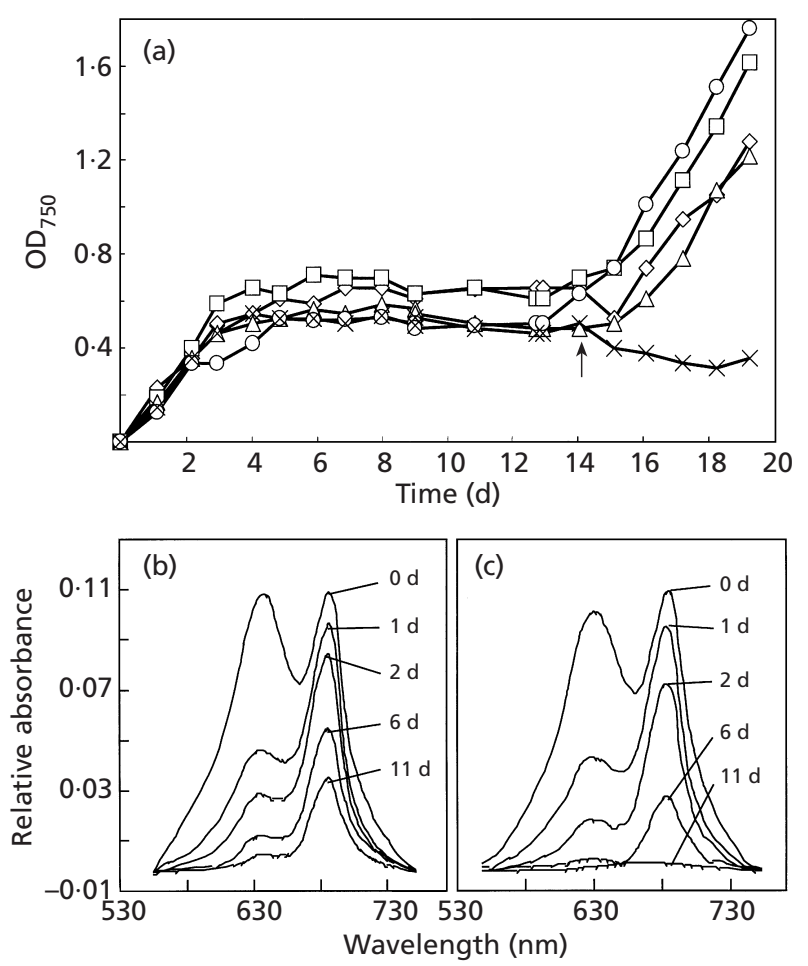

Fig. 3. (a) Restoration of growth after $\mathrm{N}$-starvation-induced stationary phase in cells of the WT and mutants SigH, SigG, SigF and RsbU of Synechocystis sp. strain PCC 6803. Cells were precultured in complete BG11 medium and then grown in $\mathrm{N}$-free BG11 for about 2 weeks. The arrow indicates the time point at which all cultures were transferred back into complete BG11 medium. Growth of the wild-type (WT 6803, $\diamond)$ and mutants $\operatorname{SigH}(\square)$, SigG $(\triangle)$, SigF $(O)$ and $\operatorname{RsbU}(\times)$ was recorded as increase in optical density at $750 \mathrm{~nm}\left(\mathrm{OD}_{750}\right)$. (b, c) Degradation of pigments was followed at different time points in cells of the wild-type (WT 6803, b) and the RsbU mutant (c) during cultivation under $\mathrm{N}$-free conditions.

were almost identical in cells of the WT and the mutants. The growth of the mutant at different $\mathrm{NaCl}$ concentrations was compared to that of WT cells in the range 2-684 mM NaCl, corresponding to $0-4 \% \mathrm{NaCl}$. No significant differences were recorded under these low and moderate salt stress conditions. Also, the content of the osmolyte glucosylglycerol did not change in any of the mutants compared to salt-shocked WT cells (Table 4). However, very strong salt shocks were found to be lethal for the SigF mutant (see Fig. 8). Interestingly, cells of the SigF mutant showed impaired mobility on agar plates used to segregate the mutant clones, whilst all other mutants were able to move on agar surfaces like WT cells. This motility defect was recently described in an independent study (Bhaya et al., 1999). However, under the cultivation conditions used in this work, our SigF mutant strain did not secrete a yellow-brown and UV-absorbing pigment as reported for the SigF mutant of Bhaya et al. (1999).

Mutants and WT were compared with respect to their ability to recover from starvation-induced stationary phase. After cultivation for two weeks in a N-deficient
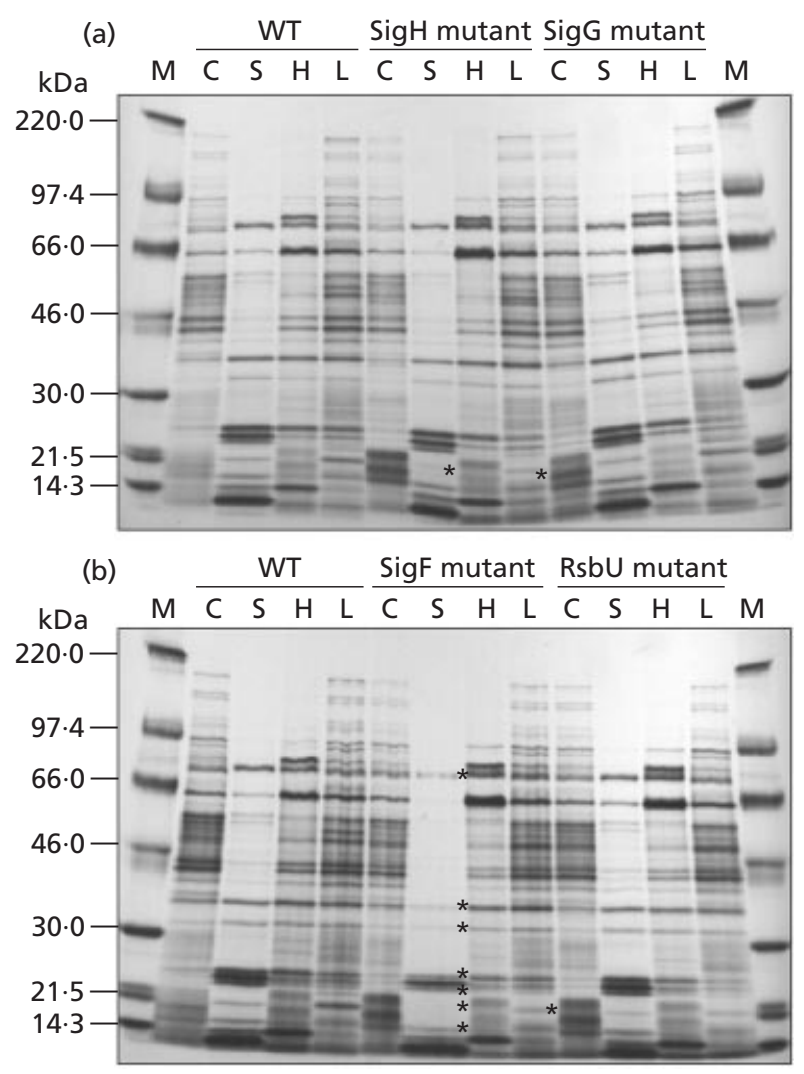

Fig. 4. Stress-induced alterations of protein synthesis pattern in cells of the WT and mutants SigH and SigG (a) and SigF and RsbU (b) of Synechocystis sp. strain PCC 6803 analysed by pulselabelling with $\left[{ }^{35} \mathrm{~S}\right]$ methionine and separation by 1D-PAGE. Cells were salt-shocked with $684 \mathrm{mM} \mathrm{NaCl}$ for $0.5 \mathrm{~h}$ (lanes S), heatshocked at $43^{\circ} \mathrm{C}$ for $0.5 \mathrm{~h}$ (lanes $\mathrm{H}$ ), or light-shocked at $2000 \mu \mathrm{mol} \mathrm{m} \mathrm{m}^{-2} \mathrm{~s}^{-1}$ for $1 \mathrm{~h}$ (lanes L). Lanes $\mathrm{M}$, molecular mass marker; lanes C, unshocked control. Asterisks indicate stress proteins absent or reduced in mutant cells.

growth medium, cells were retransferred into complete BG11 medium (Fig. 3). After a short lag phase, cells of the WT and the three Sig mutants were able to resume growth. In contrast, cells of the RsbU mutant were not able to regenerate and were completely lysed after a few days in N-replete medium. Since the stationary phase was induced by transfer of cells into $\mathrm{N}$-free medium, cells underwent a chlorotic degradation of pigments. In cells of the RsbU mutant the chlorosis occurred faster. After one week the phycobilisome peak at $630 \mathrm{~nm}$ was already absent and chlorophyll content was significantly decreased. After about $10 \mathrm{~d}$ the chlorophyll was completely degraded (Fig. 3c). At this time point, cells of the WT (Fig. 3b) and the Sig mutants (not shown) still contained residual phycobilisomes and considerable amounts of chlorophyll $a$.

\section{Protein synthesis pattern}

Alterations of gene expression were analysed in salt-, heat- and high-light-treated cells by in vivo labelling of 

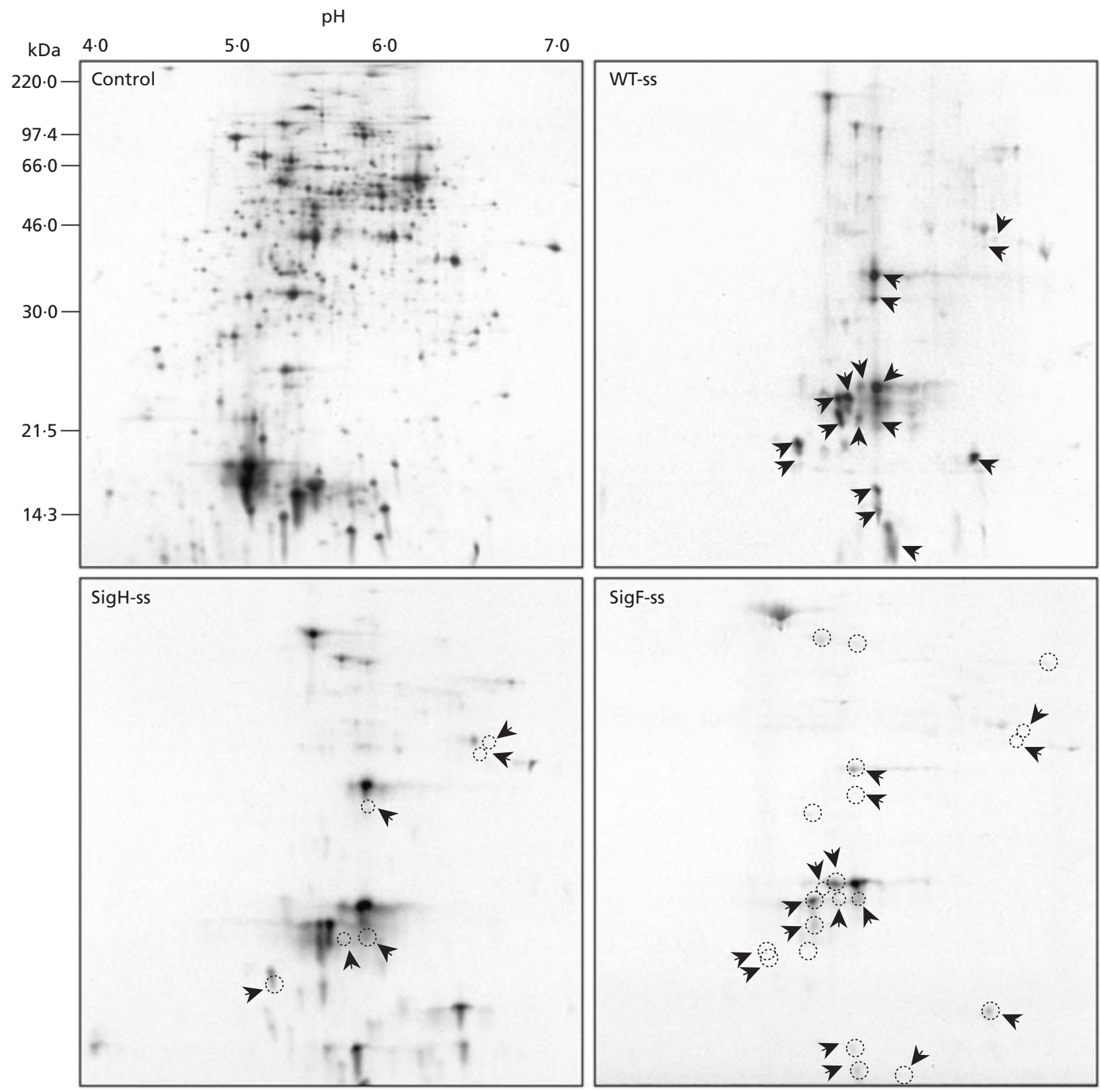

Fig. 5. Salt-stress (ss)-induced alterations of protein synthesis pattern in cells of the WT and mutants SigH and SigF of Synechocystis sp. strain 6803 analysed by pulse-labelling with $\left[{ }^{35} \mathrm{~S}\right]$ methionine and separation by 2D-PAGE. Cells were saltshocked with $684 \mathrm{mM} \mathrm{NaCl}$ for $0.5 \mathrm{~h}$. Arrows indicate positions of salt-stress proteins and dotted spots mark positions of protein spots which were absent or reduced in labelled protein extracts of mutant cells. Control, protein labelling pattern obtained in WT cells under control conditions.

proteins with $\left[{ }^{35} \mathrm{~S}\right]$ methionine and subsequent electrophoretic separation of soluble proteins from cell lysates. Results from 1D-PAGE indicated that the protein synthesis pattern was changed in salt-stressed cells of the SigF mutant (Fig. 4). Compared to cells of the WT, which exhibited a set of stress proteins expressed within $30 \mathrm{~min}$ after a salt shock of $684 \mathrm{mM} \mathrm{NaCl}$, the SigF mutant synthesized, though at a reduced rate, only three stress proteins, while the others were hardly detectable.
The response to heat and high-light shocks remained almost unchanged in cells of the SigF mutant. Only an about $16 \mathrm{kDa}$ protein, which was also induced in saltshocked cells, was clearly less labelled in a light-shocked SigF mutant (Fig. 4). The expression of a similar-sized protein was also decreased in the SigH mutant (Fig. 4). Cells of the nonsegregated mutant SigG showed no differences in stress protein labelling after 1D-separation. In SigF, SigH and RsbU mutants, expression of 

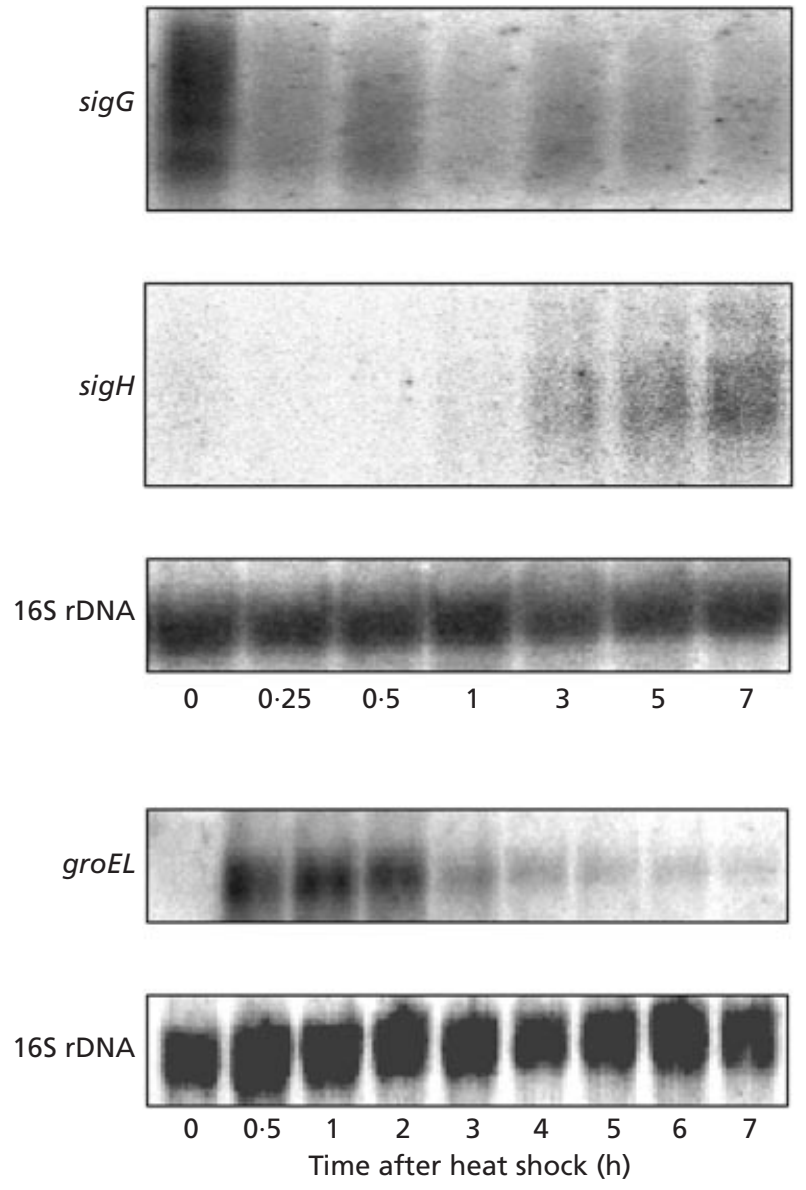

Fig. 6. Northern blot experiments to detect heat-stress-induced alterations of the steady-state mRNA levels of sigG and sigH genes in comparison to the expression of the typical heat-shock genes groEL. For hybridization, gene-specific probes were generated by PCR (see Table 2) and RNA from heat-shocked WT cells of Synechocystis sp. strain PCC $6803\left(43^{\circ} \mathrm{C}\right.$, times as indicated) was used as the target. The filters were rehybridized with a 16S-rRNA-specific probe as control for RNA loading.

the high-molecular-mass heat-shock proteins seemed to be enhanced compared to the WT (Fig. 4).

A more detailed view of stress protein synthesis patterns after salt shock was obtained by separation of soluble proteins by 2D-PAGE (Fig. 5). After cultivation under control conditions, no significant alterations were observed in the protein labelling pattern of WT and mutant cells (not shown). As expected from the 1D-gels, salt shock had a most dramatic effect on the SigF mutant (Fig. 5). Only three of the salt-stress protein spots found in WT cells remained visible. Additionally, several constitutive proteins were diminished in salt-shocked SigF mutant cells. 2D-PAGE also showed the absence of some salt-shock proteins in the SigH mutant, which were also missing in the SigF mutant (Fig. 5). Cells of mutants SigG and RsbU (not shown) showed almost the same protein synthesis pattern after salt shock as WT cells. Heat shock repressed synthesis of many proteins
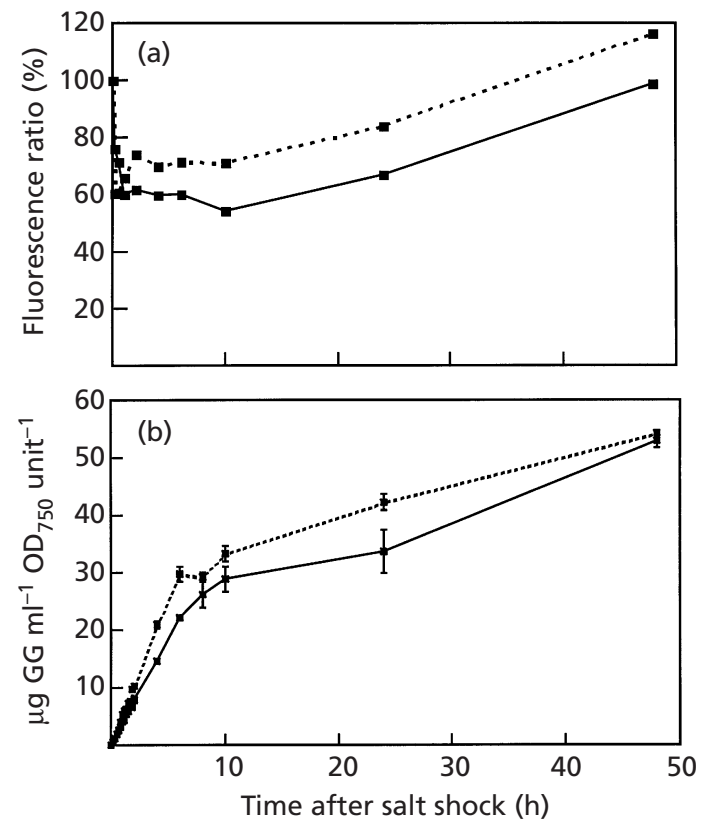

Fig. 7. Alterations of PSII fluorescence (a, ratio of $F_{v} / F_{\text {max }^{\prime}}$ relative values are shown, level of control cells was normalized to $100 \%$, see Table 4) and glucosylglycerol (GG) content (b) in cells of the WT (solid lines) and SigF mutant (broken lines) of Synechocystis sp. strain PCC 6803 shocked for different times with $684 \mathrm{mM} \mathrm{NaCl}$.

seen in control cultures. Only a few constitutive and a set of heat-shock proteins remained labelled in heatshocked WT cells. Synthesis of these heat-shock proteins was not altered in the mutants analysed in this study (not shown).

\section{Northern blot experiments}

Analysis of the expression of genes encoding regulatory proteins under different growth conditions may give additional hints towards identification of processes regulated by these proteins. Therefore, the relative mRNA amounts of the $\sigma$-factor- and the RsbU-encoding genes were estimated in Northern blot experiments using total RNA from WT cells exposed to different environmental stresses. The amount of sigF- and $r s b U$ specific mRNAs did not change significantly after applying salt, heat or high-light stress to WT cells (not shown). The sizes of the main transcripts for the sigF and $r s b U$ genes were estimated to be about 1.5 and $1.7 \mathrm{knt}$, respectively. Transcript sizes exceeded the length of probed ORFs, indicating that the genes were located on polycistronic mRNAs containing adjacent genes (compare Fig. 1). Clear responses to salt- and heatstress treatments, but not towards light stress, were found in the transcript levels of the $\operatorname{sig} G$ and $\operatorname{sig} H$ genes. In control cells, sig $G$ mRNA was clearly detectable and that of sigH nearly absent, whilst in heat- and saltstressed cells the sigH mRNA amount exceeded that of 
(a) Salt stress

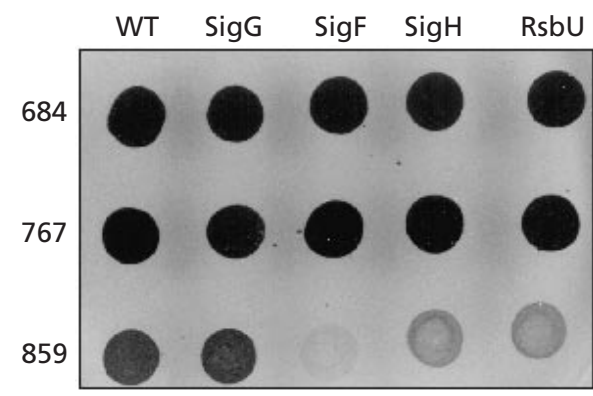

(b) Nutrient starvation

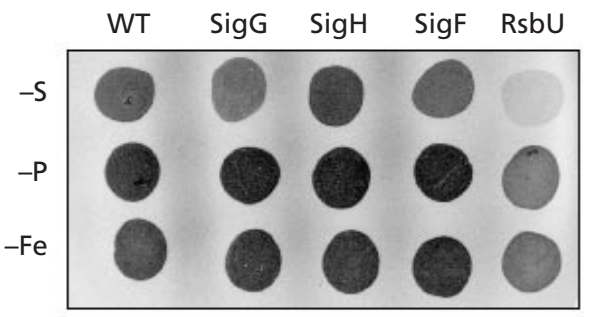

(c) High light stress

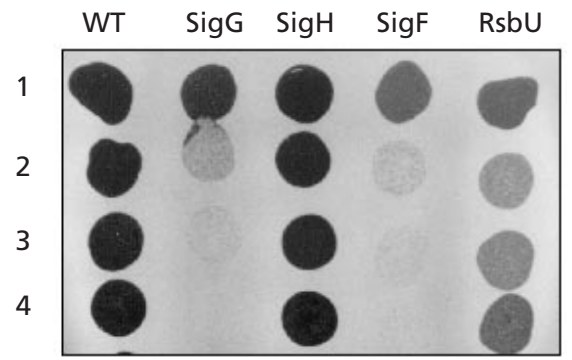

Fig. 8. Survival of extreme stress treatments by cells of the WT and SigF, SigG, SigH and RsbU mutants of Synechocystis sp. strain PC 6803. Cells were incubated for different times under stress conditions and thereafter aliquots were dropped onto control medium to evaluate survival of cells. (a) Cells were incubated for $2 \mathrm{~d}$ at different $\mathrm{NaCl}$ concentrations as indicated $(\mathrm{mM}) ;(\mathrm{b})$ cells were incubated for 3 weeks in S-, P- and Fe-free BG11 medium; (c) cells were exposed for different times as indicated (h) to a high light intensity of $1500 \mu \mathrm{mol}$ photons $\mathrm{m}^{-2} \mathrm{~s}^{-1}$.

$\operatorname{sig} G$ (Fig. 6). Maximal expression of $\operatorname{sig} H$ was detected only $7 \mathrm{~h}$ after the application of a heat shock of $43^{\circ} \mathrm{C}$. At this time, the transiently activated expression of the heat-shock genes groEL was already reduced nearly to the control level (Fig. 6). Quantitative analyses revealed that the amount of $\operatorname{sig} H$-specific mRNA increased about 30 -fold in heat-shocked cells and 2.5-fold in salt-shocked cells, whilst the $\operatorname{sig} G$-specific mRNA level was reduced to about 20 and $50 \%$, respectively. The signal obtained for the mRNAs in Northern blot experiments was smeared, indicating low stability of these transcripts. In the case of $\operatorname{sigH}$, the estimated full-length transcript of about $0.7 \mathrm{knt}$ corresponded well to the length of its coding sequence, whilst a full-length transcript of at least $1.0 \mathrm{knt}$ was observed for $\operatorname{sig} G$, which clearly exceeds the size of its coding region. The nearly complete disappearance of $\operatorname{sig} G$-specific mRNA in salt- and heatstressed cells led to the assumption that under these growth conditions this $\sigma$-factor could be dispensable. However, in both salt-treated and high-temperature treated cells, again no complete segregation of the SigG mutant was achieved.

\section{Salt tolerance of the SigF mutant}

Although salt-treated cells of the SigF mutant exhibited a strongly decreased level of stress protein synthesis, cells were still able to grow at a salt concentration of $684 \mathrm{mM} \mathrm{NaCl}$ in $\mathrm{CO}_{2}$-gassed cultures. Since most saltstress proteins of Synechocystis are only transiently detectable (Hagemann et al., 1991), it may be concluded that those proteins are only important during the early acclimation phase. Therefore, investigations of the early salt acclimation process were performed using WT and SigF mutant cells (Fig. 7). Photosynthesis measured as the ratio of variable and maximal photosystem II fluorescence and glucosylglycerol accumulation were chosen as parameters to evaluate a successful salt acclimation. In both cases, cells of the SigF mutant showed no sign of an enhanced lag phase or any delay in the acclimation process. In both the WT and SigF strains, photosynthesis was immediately diminished in cells shocked by $684 \mathrm{mM} \mathrm{NaCl}$. A decreased fluorescence ratio was observed during the first $10 \mathrm{~h}$ after salt shock, whilst it recovered to the control level parallel to glucosylglycerol accumulation during further acclimation (Fig. 7). Additionally, the resistance to very high salt concentrations of the SigF mutant was compared to WT cells and that of the other mutants in BG11 medium. In these experiments, a decrease in the maximal salt tolerance level of the SigF mutant became obvious (Fig. 8). After $7 \mathrm{~d}$ incubation at $855 \mathrm{mM}(5 \%) \mathrm{NaCl}$, cells of the SigF mutant were completely lysed and could not recover under optimal growth conditions, whilst all other mutants and the WT survived such a stress condition. Exposure of cells to $1 \mathrm{M} \mathrm{NaCl}$ was found to be lethal for the WT as well as the mutants (not shown).

\section{Survival after extreme stress treatments}

Under control conditions and moderate stress we did not observe any significant alterations in the phenotype of the mutants in comparison to WT cells. This may not be the case when these cells are exposed to harsh stresses, as was found for extreme high-salt stress. Therefore, mutants were deprived for up to 5 weeks of different nutrients as described in Methods. As after Nstarvation (see Fig. 3), the RsbU mutant was again not able to recover after long term S-starvation, whilst the Sig mutants and the WT strains survived this treatment (Fig. 8). Long-term P- and Fe-starvations were tolerated by all strains. In further experiments, the cells were exposed to high and low temperatures. A heat shock of $45^{\circ} \mathrm{C}$ for $3-4 \mathrm{~h}$ was found to be lethal for all strains (not shown). In a few experiments, cells of the SigH mutant showed a tendency to be damaged earlier than the other 
cells. The incubation of mutant and WT at low temperatures $\left(4^{\circ} \mathrm{C}\right)$ for several days was tolerated by all cultures (not shown). Exposure of cells to about $1500 \mu \mathrm{mol}$ photons $\mathrm{m}^{-2} \mathrm{~s}^{-1}$ for $2-3 \mathrm{~h}$ at $29^{\circ} \mathrm{C}$ was found to be lethal for cells of the SigF mutant and, surprisingly, also for the nonsegregated mutant SigG (Fig. 8). Cells of the WT as well as the SigH and RsbU mutant tolerated this stress treatment for at least $5 \mathrm{~h}$.

\section{DISCUSSION}

To study the role of alternative $\sigma$-factors in the acclimation of Synechocystis to environmental stresses, genes encoding putative group $3 \sigma$-factors and one regulatory protein were disrupted using interposon mutagenesis. Only the $\sigma$-factor SigG (Slr-1545) was found to be essential for Synechocystis cells. A similar result has been demonstrated for its close homologue RpoE from E. coli, indicating that this $\sigma$-factor is involved in the expression of essential genes under ambient temperature (Missiakas \& Raina, 1998). In accordance with a possible involvement of SigG in transcription under standard growth conditions, the highest mRNA level of this gene was found in cells grown under these conditions. This putative $\sigma$-factor of Synechocystis also showed high similarities to the second ECF- $\sigma$-factor FecI of E. coli (Van Hove et al., 1990), which is involved in the regulation of iron uptake. However, the SigG mutant survived a long-term iron starvation without any remarkable phenotypic changes. Because of its merodiploid status, it was not surprising that almost no phenotypical alterations were detected in the SigG mutant compared to WT cells. Only under high-light conditions was a clearly reduced survival time of cells of the SigG mutant found. Possibly, the reduced gene dosage of WT $\operatorname{sig} G$ in the mutant led to a reduced expression of protein(s) required to prevent lesions caused by high light. In photosynthetic cells, high light intensities induce oxidative stress and it is intriguing to see that RpoE-like $\sigma$-factors of E. coli are also involved in response to oxidative stress (Missiakas \& Raina, 1998).

SigH (Sll-0856), the second RpoE homologue of Synechocystis, was found to be dispensable. The fully segregated mutant was able to tolerate all growth and stress conditions used in this study. The two rpoE gene homologues of Synechocystis seem to be complementarily regulated. The $\operatorname{sig} H$ transcript increased when the cells were subjected to heat-shock conditions, whilst the transcript of $\operatorname{sig} G$ decreased under these conditions. However, compared to the induction of the typical heatshock genes groEL, the induction of sigH occurred rather late making it unlikely that the alternative $\sigma$ factor $\mathrm{SigH}$ is responsible for the regulation of these heat-shock genes. Furthermore, since the sig $G$ gene could not be completely deleted, it seems that the SigH cannot functionally replace the essential SigG.

The completely segregated SigF mutant of Synechocystis exhibited a pronounced defect in salt-stress-induced gene expression. Most of the stress proteins were absent in salt-shocked cells of this mutant, whilst levels of proteins induced by heat and high-light shock were almost unchanged. Despite the reduction in the synthesis of salt stress proteins, during the first hours after a salt shock no differences were observed regarding glucosylglycerol accumulation and recovery of photosynthesis. However, long term application of high-salt stress clearly diminished the survival rate of the SigF mutant in comparison to WT cells. These results indicate that the salt-shock proteins are most important for the long-term salt acclimation and tolerance of salt concentrations near the resistance level. But they are apparently not required for glucosylglycerol synthesis and ion export, two processes shown to be mainly regulated by posttranslational activation of pre-existing enzymes (Hagemann et al., 1996). Until now most of the proteins induced by salt stress were unknown. Many of them were also found after other stress treatments, therefore they can be regarded as general stress proteins (Fulda $e t$ al., 1999; Hagemann et al., 1991). The specific effect of salt, demonstrated in the phenotype of the SigF mutant, provides evidence that SigF represents a terminal element of a signal-transducing pathway sensing salt. This pathway apparently targets unknown stress proteins and proteins involved in the synthesis of pili, required for light-induced mobility of Synechocystis (Bhaya et al., 1999).

The induction of salt-stress proteins seems to be primarily regulated by modulation of the activity of the SigF protein, since sigF transcription remained almost constant in stressed cells. Post-translational regulation is characteristic of the structurally similar SigB in $B$. subtilis (Hecker et al., 1996) and the functionally similar RpoS in E. coli (Hengge-Aronis, 1996), two $\sigma$-factors that are required for the increased expression of several genes after a salt or osmotic shock. However, in contrast to SigB of B. subtilis, the SigF of Synechocystis seems not to be involved in transition to stationary phase since our SigF mutant did not show any phenotype regarding its ability to resume growth after starvation-induced stationary phase. Remarkably, a deletion of $r s b U$, encoding a close homologue of a regulatory protein involved in the activation cascade of SigB in B. subtilis (Völker et al., 1995; Hecker et al., 1996), showed a defect in recovering from stationary phase but no defect in inducing salt stress proteins and survival of high-salt and high-light stress treatments. Besides N-starvationinduced stationary phase, the RsbU mutant could not survive long-term S-starvation. Thus, in Synechocystis RsbU is not involved in the activation of SigF to drive salt-induced gene expression, but may participate in the response to nutrient deficiency, which includes a controlled degradation of phycobiliproteins followed by chlorophyll a (Sauer et al., 1999). In the cyanobacterial strain Synechococcus sp. strain PCC 7002, a group $2 \sigma$ factor called SigE was identified and found to be responsible for stationary-phase-induced gene activation (Gruber \& Bryant, 1998). However, further studies will be required to show that RsbU eventually functions 
in regulation of group $2 \sigma$-factors in Synechocystis and other cyanobacteria.

\section{ACKNOWLEDGEMENTS}

We would like to thank Professor D. A. Bryant, Pennsylvania State University, USA, and Professor M. Hecker, ErnstMoritz-Arndt University Greifswald, Germany, for critical reading of the manuscript. The excellent technical assistance of Chem. Ing. K. Sommerey and Ms B. Brzezinka is greatly appreciated. The work was supported by a grant from the Deutsche Forschungsgemeinschaft (DFG).

\section{REFERENCES}

Allen, M. B. \& Arnon, D. I. (1955). Studies on nitrogen fixing bluegreen algae. II. The sodium requirement of Anabaena cylindrica. Physiol Plant 8, 653-660.

Altschul, S. F., Madden, T. L., Schaffer, A. A., Zhang, J., Zhang, Z., Miller, W. \& Lipman, D. J. (1997). Gapped BLAST and PSI-BLAST : a new generation of protein database search programs. Nucleic Acids Res 25, 3389-3402.

Asayama, M., Suzuki, A., Nozawa, S., Yamada, A., Tanaka, K., Takahashi, H., Aida, T. \& Shirai, M. (1997). A new sigma factor homolog in a cyanobacterium: cloning, sequencing, and lightresponsive transcripts of $r p o D 2$ from Microcystis aeruginosa K81. Biochim Biophys Acta 1351, 31-36.

Bhaya, D., Watanabe, N., Ogawa, T. \& Grossman, A. R. (1999). The role of an alternative sigma factor in motility and pilus formation in the cyanobacterium Synechocystis sp. strain PCC6803. Proc Natl Acad Sci U S A 96, 3188-3193.

Brahamsha, B. \& Haselkorn, R. (1992). Identification of multiple RNA polymerase sigma factor homologs in the cyanobacterium Anabaena sp. strain PCC 7120: cloning, expression, and inactivation of the $\operatorname{sig} B$ and sigC genes. J Bacteriol 174, 7273-7282.

Cambell, E. L., Brahamsha, B. \& Meeks, J. C. (1998). Mutation of an alternative sigma factor in the cyanobacterium Nostoc punctiforme results in increased infection of its symbiotic plant partner, Anthoceros punctatus. J Bacteriol 180, 4938-4941.

Caslake, L. F., Gruber, T. M. \& Bryant, D. A. (1997). Expression of two alternative sigma factors of Synechococcus sp. strain PCC 7002 is modulated by carbon and nitrogen stress. Microbiology 143, 3807-3818.

Fulda, S., Huckauf, J., Schoor, A. \& Hagemann, M. (1999). Analysis of stress responses in the cyanobacterial strains Synechococcus sp. PCC 7942, Synechocystis sp. PCC 6803, and Synechococcus sp. PCC 7418: osmolyte accumulation and stress protein synthesis. J Plant Physiol 154, 240-249.

Goto-Seki, A., Shirokane, M., Masuda, S., Tanaka, K. \& Takahashi, H. (1999). Specificity crosstalk among group 1 and group 2 sigma factors in the cyanobacterium Synechococcus sp. PCC7942: in vitro specificity and a phylogenetic analysis. Mol Microbiol 34, 473-484.

Gross, C. A. (1996). Function and regulation of heat shock proteins. In Escherichia coli and Salmonella: Cellular and Molecular Biology, 2nd edn, vol. I, pp. 1382-1399. Edited by F. C. Neidhardt and others. Washington, DC: American Society for Microbiology.

Gruber, T. M. \& Bryant, D. A. (1997). Molecular systematic studies of eubacteria, using $\sigma^{70}$-type sigma factors of group 1 and group 2. J Bacteriol 179, 1734-1747.

Gruber, T. M. \& Bryant, D. A. (1998). Characterization of the alternative $\sigma$-factors SigD and SigE in Synechococcus sp. strain
PCC 7002. SigE is implicated in transcription of post-exponentialphase-specific genes. Arch Microbiol 169, 211-219.

Hagemann, M. \& Zuther, E. (1992). Selection and characterization of mutants of the cyanobacterium Synechocystis sp. PCC 6803 unable to tolerate high salt concentrations. Arch Microbiol 158, 429-434.

Hagemann, M., Techel, D. \& Rensing, L. (1991). Comparison of salt- and heat-induced alterations of protein synthesis in the cyanobacterium Synechocystis sp. PCC 6803. Arch Microbiol $155,587-592$.

Hagemann, M., Schoor, A. \& Erdmann, N. (1996). $\mathrm{NaCl}$ acts as a direct modulator in the salt adaptive response: salt-dependent activation of glucosylglycerol synthesis in vivo and in vitro. $J$ Plant Physiol 149, 746-752.

Hagemann, M., Schoor, A., Jeanjean, R., Zuther, E. \& Joset, F. (1997). The gene stpA from Synechocystis sp. strain PCC 6803 encodes the glucosylglycerol-phosphate phosphatase involved in cyanobacterial salt adaptation. J Bacteriol 179, 1727-1733.

Hecker, M., Schumann, W. \& Völker, U. (1996). Heat-shock and general stress response in Bacillus subtilis. Mol Microbiol 19, 417-428.

Hengge-Aronis, R. (1996). Back to $\log$ phase: $\sigma^{\mathrm{s}}$ as a global regulator in the osmotic control of gene expression in Escherichia coli. Mol Microbiol 21, 887-893.

Kaneko, T., Sato, S., Kotani, H. \& 21 other authors (1996). Sequence analysis of the genome of the unicellular cyanobacterium Synechocystis sp. strain PCC 6803. II. Sequence determination of the entire genome and assignment of potential protein-coding regions. DNA Res 3, 109-136.

Kato, F., Hino, T., Nakaji, A., Tanaka, M. \& Koyama, Y. (1995). Carotenoid synthesis in Streptomyces setonii ISP5395 is induced by the gene $c r t S$, whose product is similar to a sigma factor. Mol Gen Genet 247, 387-390.

Kratz, W. A. \& Myers, J. (1955). Nutrition and growth of several blue-green algae. Am J Bot 42, 282-287.

Lane, D. J. (1991). 16S/23S rRNA sequencing. In Nucleic Acid Techniques in Bacterial Systematics, pp. 115-175. Edited by E. Stackebrandt \& M. Goodfellow. Chichester: Wiley.

Martin, D. W., Holloway, B. W. \& Deretic, V. (1993). Characterization of a locus determining the mucoid status of Psendomonas aeruginosa: $\operatorname{AlgU}$ shows sequence similarities with a Bacillus sigma factor. J Bacteriol 175, 1153-1164.

Missiakas, D. \& Raina, S. (1998). The extracytoplasmic function sigma factors: role and regulation. Mol Microbiol 28, 1059-1066.

Potuckova, L., Kelemen, G. H., Findlay, K. C., Lonetto, M. A., Buttner, M. J. \& Kormanec, J. (1995). A new RNA polymerase sigma factor, sigma $\mathrm{F}$, is required for the late stages of morphological differentiation in Streptomyces spp. Mol Microbiol 17, 37-48.

Reed, R. H. \& Stewart, W. D. P. (1985). Osmotic adjustment and organic solute accumulation in unicellular cyanobacteria from freshwater and marine habitats. Mar Biol 88, 1-9.

Rippka, R., Deruelles, J., Waterbury, J. B., Herdman, M. \& Stanier, R. Y. (1979). Generic assignments, strain histories and properties of pure cultures of cyanobacteria. J Gen Microbiol 111, 1-61.

Sambrook, J., Fritsch, E. F. \& Maniatis, T. (1989). Molecular cloning: a Laboratory Manual, 2nd edn. Cold Spring Harbor, NY: Cold Spring Harbor Laboratory.

Sauer, J., Görl, M. \& Forchhammer, K. (1999). Nitrogen starvation in Synechococcus PCC 7942: involvement of glutamine synthetase and NtcA in phycobiliprotein degradation and survival. Arch Microbiol 172, 247-255. 
Sigalat, C. \& de Kouchkovsky, Y. (1975). Fractionnement et caractérisation de l'appareil photosynthétique de l'algue bleue unicellulaire Anacystis nidulans. Physiol Veg 13, 243-258.

Tsinomeras, N. F., Ishiura, M., Kondo, T., Anderson, C. R., Tanaka, K., Takahashi, H., Johnson, C. H. \& Golden, S. S. (1996). A sigma factor that modifies the circadian expression of a subset of genes in cyanobacteria. EMBO J 15, 2488-2495.

Van Hove, B., Staudenmaier, H. \& Braun, V. (1990). Novel twocomponent transmembrane transcription control: regulation of iron dicitrate transport in Escherichia coli K-12. J Bacteriol 172, 6749-6758.

Völker, U., Dufour, A. \& Haldenwang, W. G. (1995). The Bacillus subtilis rsbU gene product is necessary for RsbX-dependent regulation of sigma B. J Bacteriol 177, 114-122.

Webb, R. \& Sherman, L. A. (1994). The cyanobacterial heat-shock response and the molecular chaperones. In Molecular Biology of Cyanobacteria, pp. 581-611. Edited by D. A. Bryant. Dordrecht: Kluwer.

Wösten, M. M. S. M. (1998). Eubacterial sigma-factors. FEMS Microbiol Rev 22, 127-150.

Received 29 February 2000; revised 26 July 2000; accepted 4 August 2000. 